\title{
THE INFLUENCE OF BOVINE THYMIC EXTRACT ON THE IMMUNE RESPONSE IN IRRADIATED WISTAR RATS
}

JOVANOVIĆ $\mathrm{M}^{\star}$, LAZAREVIĆ $\mathrm{M}^{\star}$, POPOVIĆ $\mathrm{N}^{\star}$ and VOJVODIĆ $\mathrm{D}^{\star *}$

\author{
*Faculty of veterinary medicine, Belgrade, Serbia \\ **Military medical academy, Belgrade, Serbia \\ (Recieved 1 $17^{\text {th }}$ November, 2008)
}

Immunomodulation is a phenomenon that is based on the influence of different endogenous and exogenous substances on the function of molecules and cells pertaining to the immune system. Some components extracted from the bovine thymus have immunomodulating features and can, both in animals and humans, by suppressing the immune response (humoral and/or cellular) bring about immunostimulation and increased organism resistance. In this paper the effects of bovine thymus extract (Thymex - L) on the parameters of humoral immune response (concentration of antibodies to tetanus toxoid - ATTX) and cellular immune response (interleukin 2 IL-2, interferon $\gamma-$ IFN- $\gamma$ and degree of cutaneus basophyl hypersensitivity - CBHR) in rats previously irradiated by X-rays at a dose of 4 or 6 Gy.

The studied thymus extract had shown positive effects on IL-2 and IFN- $\gamma$ serum concentrations in irradiated rats. In the group of rats irradiated with 4 Gy the effects were evident on the $7^{\text {th }}$ day of the trial. Rats irradiated with the higher dose (6 Gy) experienced the positive effects of thymus extract on the 21st day of the experiment. In the skin PHA hypersensitivity test, a positive effect was also recorded, being more pronounced in rats which received the lower irradiation dose. The tested thymus extract had shown a positive effect on the concentration of ATTx as early as the $14^{\text {th }}$ day of the trial.

Key words: bovine thymus extract, cellular immune response, humoral immune response, irradiation, immunomodulation, rats

\section{INTRODUCTION}

Immunomodulation is a phenomenon that is based on the influence of different endogenous and exogenous substances on the function of molecules and cells pertaining to the immune system. Immunomodulators are substances capable of influencing the immune response by either suppressing or enhancing it. The majority of immunomodulators increases or decreases the immune reaction without displaying any specificity towards the antigen. Some substances 
can display both effects depending on the dose and mode of application (Nesterova, 1999; Tizard and Schubot, 2004).

The main target cells of immunomodulatory substances are the $\mathrm{T}$ and $\mathrm{B}$ lymphocytes, monocytes, macrophages and granulocytes. The way in which immunomodulators act on these cells is not always easy to determine. It is considered that the majority causes changes in the structure of cyclic nucleotides: cyclic adenosine monophosphate and cyclic guanosine monophosphate in the cytoplasm of immunocompetent cells (Nesterova, 1999).

Application of some immunosuppressant substances is important for the remission of auto-reactive conditions, allergic reactions and in the inhibition of rejection of transplanted organs. Procedures and substances which suppress the immune reaction can be classified into two large groups: antigen dependent nonspecific suppressors and antigen dependant specific suppressors (Lake et al., 2001)

The techniques used to suppress the activity of immune system cells were mainly based on the application and effects of X-rays or drugs used to inhibit cell division. The immunosuppressive effects of ionizing radiation are based on its effects on nucleic acids, resulting in undesired mutations with potential latent lethal effects on offspring cells. Irradiated cells show an increased rate of peroxide production and subsequent toxic effects (Bethesda, 2001). The effects of different doses of ionizing radiation on the thymus and other organs can be observed on the basis of histological changes, as well as on the concentrations of some serum cytokines (Coggle, 1981; Mizutani et al., 2002; Tokuda et al., 2004).

A large number of peptides extracted from the thymus display an immunostimulatory effect. The following hormones were extracted from the thymic cells: thymosine, thymic humoral factor, thymopoietin, thymostimulin and thymulin. These hormones stimulate T-lymphocyte maturation and differentiation, thus enhancing the activity of Th-lymphocytes, release of interleukin-2 (IL-2), as well as the effects of Tc lymphocytes. Thymostimulin improves the production of interferon- $\gamma$ (IFN- $\gamma$ ), thymosine boosts resistance to viral infections (Benedikt, 2000; Munno et al., 1995; Wilson, 1999). There is clear evidence that thymus extract has effects on the function of B lymphocytes (Twomey and Koutab, 1982). However, the strongest effect of thymus preparations is on the cellular immune response, targeting T lymphocytes including helpers, suppressors, cytotoxic, TK, NK and macrophages. The thymus extract acts upon the production, maturation and activation of T lymphocytes and macrophages, and stimulates the maturation of immature thymocytes (T6 cells) to T3 cells in the bone marrow. Thymus extract extract increases the number of mature $T$ cells and stimulates the functions of $T$ lymphocytes, such as Th (T4) and Ts (Twomey and Koutab, 1982).

Some of the thymic hormones express positive therapeutic effects, but their application in medicine is still not clear. The most common use of thymic hormones is in the therapy of respiratory disorders, different infections, immunodeficiency disorders, skin disorders, neoplasms, and following some surgical procedures. Barbaroza et al. (2000) have described the use of thymus extract in therapy of different diseases in few animal species (dogs, rabbits and pigs). 


\section{MATERIAL AND METHODS}

The experiment was carried out on a total of 230 inbred Wistar male rats, 3 months old and 200-300 g body mass. The experimental animals were kept in stable microclimatic conditions at $18-22^{\circ} \mathrm{C}$, fed standard chew with ad libitum access to water. The rats were allotted into separate polypropylene cages, 5 rats per cage, divided into 4 experimental groups: A and B (80 rats/group) and C $(n=40)$ and $K(n=30)$. At the very start of the study (day zero) blood samples of all experimental animals were taken from the medial eye angle, thereof animals were left to recover for a week before continuing the experiment.

Experimental groups $A$ and $B$ ( 80 rats/group) were irradiated on the first day of the experiment with 4 Gy and 6 Gy respectively. These groups were divided into two subgroups $\left(A_{1}\right.$ and $A_{2} ; B_{1}$ and $\left.B_{2}\right)$ with 40 rats in each subgroup. In order to follow up the immune response to the tetanus toxoid all experimental animals were immunized with the antitetanus vaccine (TETAVAKSAL-T ${ }^{\circledR}$, Institute for Immunology and Virusology, Torlak), on the second day of the trial. After two weeks the studied rats were revaccinated. The subgroups $A 1$ and $B 1$ were treated with $0.2 \mathrm{~mL} / \mathrm{rat}$ saline up to the end of the trial every other day. Subgroups A2 and B2 were treated at the same time intervals with calf thymus extract.

Experimental group $\mathrm{C}$ consisted of 40 rats randomly allotted to 4 subgroups (C1- C4). Rats from subgroups $\mathrm{C} 1$ and $\mathrm{C} 2$ were irradiated with 4 Gy and groups C3 and C4 with 6 Gy, respectively. Thereof, rats from subgroups $\mathrm{C} 1$ and $\mathrm{C} 3$ were treated with saline $0.2 \mathrm{~mL} / \mathrm{rat}$, and rats from groups $\mathrm{C} 2$ and $\mathrm{C} 4$ with calf thymus extract every second day. Rats from group $\mathrm{C}$ were not vaccinated and were considered as the control group for humoral immune response to TTX.

The fourth experimental (control group K) consisted of 30 rats which were not previously irradiated. They were allotted to 3 subgroups (10 rats each), and described as $\mathrm{K} 1, \mathrm{~K} 2$ and $\mathrm{K} 3$. the second day of the experiment, rats from subgroups $\mathrm{K} 1$ and $\mathrm{K} 2$ were groups immunized with antitetanus vaccine (TETAVAKSAL-T ${ }^{\circledR}$ ), in order to follow the humoral immune response to this antigen. After 14 days they were revaccinated. Animals from groups K1 and K3 were treated with saline $(0.2 \mathrm{~mL} / \mathrm{rat})$, and rats from group $\mathrm{K} 2$ were treated every other day with calf thymus extract.

On the fourth day of the experiment blood samples from 10 rats from subgroups A1, A2, B1 and B2 were taken from the medial eye sinus. Thereof, on the 6 th day of the trial the skin thickness of the knee skin fold was measured on both sides of the body. Phytohemagglutinin (PHA) was applied on the right side, and phosphate buffered solution (PBS) on the left side of the body. On the seventh day skin thickness of the knee skin fold was measured once again. The animals were than introduced into ether anesthesia, blood samples from the abdominal aorta were taken and the animals were than humanely euthanized. This treatment was repeated on 10 rats of the above mentioned subgroups in 7 day intervals until the end of the survey.

Blood from the medial eye angle was drawn on days 0 and 14 from animals of the third experimental group $C(C 1-C 4)$. On experimental day 28 blood was 
drawn from the abdominal aorta in ether anesthesia after which they were sacrificed.

The fourth experimental group, the $\mathrm{K}$ control group, underwent the following treatment: on day 27, rats of subgroups $\mathrm{K} 1$ and $\mathrm{K} 2$ received PHA for skin sensitivity testing. On day 28 all animals were introduced into short ether anesthesia, blood was drawn and they were sacrificed.

Rat irradiation

Rats were irradiated as to produce immunosuppression. Irradiation was performed by a linear accelerator SLiELEKTRA. The dosage was 4 and 6 Gy at a $5 \mathrm{~cm}$ depth, using SSD technique (source to skin distance $100 \mathrm{~cm}$ ) with an irradiation field $35 \times 35 \mathrm{~cm}$. The energy of the rays was $4 \mathrm{MV}$.

Thymus extract application

THYMEX-L (THYMOORGAN-GmbH PHARMAZIE \&Co. KG, Germany) was used as an immunostimulator to treat the rats. One vial of this drug contains $150 \mathrm{mg}$ of the total thymus extract THX, according to dr Pesic, isolated from young, fresh, veal thymi, standardized according to protein content. The content of suspended protein is $0.6 \mathrm{mg} / \mathrm{mg}$, at $\mathrm{pH} 7.1$ and $37^{\circ} \mathrm{C}$. Besides immunogenic peptides and proteins, THYMEX-L contains also active adenosinedeaminases, purine nucleoside phosphatases, superoxide dismutase, glutathione reductase, glutathion-S-transferase, glutathione peroxidase and peptidase. One vial of THYMEX-L is dissolved in $2 \mathrm{~mL}$ aqua pro injectione. The experimental animals were treated every other day with $0.2 \mathrm{~mL}$ of extract for each animal or $9 \mathrm{mg}$ of protein per animal. Exract was administered subcutaneously every other day with the last injection on the $26^{\text {th }}$ day of the experiment.

Assessment of the cellular immune response

The evaluation of the cellular immune response was monitored by IL-2 and IFN- $\gamma$ ELISA tests. We used commercially prepared module sets for IL-2 DuoSet ${ }^{\circledR}$ ELISA Development System Rat IL-2 produced by R\&D System Inc. Minneapolis USA. We have tested IFN- $\gamma$ concentration in the sera of irradiated rats with ready made rat sets BMS621MST produced by Bender MedSystems GmbH, Vienna, Austria. The results were determined on Behring ELISA processor II apparatus according to the manufacturer's procedure.

Assessment of the humoral immune response

Rats were immunized with a commercial vaccine TETRAVAKSAL-T ${ }^{\circledR}$ (Institute for immunology and virology Torlak). This vaccine is designed for human use, so that for rat immunization the contents of one vial $(0.5 \mathrm{~mL})$ were diluted with $4.5 \mathrm{~mL}$ aqua pro injectione. Every rat from groups $\mathrm{A}, \mathrm{B}, \mathrm{K} 1$ and $\mathrm{K} 2$ received $0.1 \mathrm{~mL}$ intramuscularly and revaccination was carried out after 14 days. Antibody content was determined by ELISA (Simensen et al., 1986; Vos et al., 1979) on a Behring ELISA Processor II (Germany).

Cutaneous hyper-reactivity test (CBHR)

Cutaneous hyper-reactivity was tested injecting intradermally $100 \mu \mathrm{g}$ of phytohemagglutinin (PHA) in a $0.1 \mathrm{~mL}$ solution into the knee skin fold of the rats' right leg. Simultaneously, the same volume of PBS (phosphate buffered solution, $\mathrm{pH}$ 7.2) was injected into the left knee skin fold. These tests were carried out on 
days $0,6,13,20$ and 27 of the experiment. The degree of reaction was estimated after 24 hours. The degree of reactivity was calculated from the difference of skin thickness on the right and left sides. Skin thickness was gauged to $0.1 \mathrm{~mm}$ accuracy. Changes resulting from the KHO test were calculated using the appropriate formula (Smits et al., 1999; Goto et al., 1978; Graeves and Roitt, 1968).

Statistical analysis

Statistical analysis was done after mean and standard deviation calculations. Significance was tested using the Student $\mathrm{t}$ - test.

\section{RESULTS}

Our results are presented in figures 1 to 4 . The level statistically significant differences observed between experimental groups of rats during the 28 day testing period is shown in Tables 1 and 2.

Table 1. Statistical differences in concentrations of IL-2 and IFN- g, between experimental groups of rats

\begin{tabular}{|c|c|c|c|c|c|}
\hline & & $A_{1}$ vs $A_{2}$ & $\mathrm{~B}_{1}$ vs $\mathrm{B}_{2}$ & $A_{1}$ vs $B_{1}$ & $A_{2}$ vs $B_{2}$ \\
\hline \multirow{2}{*}{4 day } & IL-2 & NS & NS & NS & NS \\
\hline & IFN- $\gamma$ & NS & NS & NS & NS \\
\hline \multirow{2}{*}{7 day } & IL-2 & NS & NS & NS & NS \\
\hline & IFN- $\gamma$ & * & NS & * & NS \\
\hline \multirow{2}{*}{11 day } & IL-2 & $* *$ & NS & $\star$ & NS \\
\hline & IFN- $\gamma$ & * & NS & NS & NS \\
\hline \multirow{2}{*}{14 day } & IL-2 & * & NS & NS & NS \\
\hline & IFN- $\gamma$ & NS & $\star \star$ & NS & NS \\
\hline \multirow{2}{*}{18 day } & IL-2 & * & NS & NS & NS \\
\hline & IFN- $\gamma$ & NS & NS & NS & NS \\
\hline \multirow{2}{*}{21 day } & IL-2 & NS & * & $\star \star$ & * \\
\hline & IFN- $\gamma$ & NS & * & NS & NS \\
\hline \multirow{2}{*}{25 day } & IL-2 & $* *$ & $\star *$ & $\star *$ & ** \\
\hline & IFN- $\gamma$ & NS & NS & NS & NS \\
\hline \multirow{2}{*}{28 day } & IL-2 & $\star \star \star *$ & * & * & * \\
\hline & IFN- $\gamma$ & $* *$ & * & NS & NS \\
\hline
\end{tabular}

NS - non significant; ${ }^{*} p<0.05 ;{ }^{* *} p<0.01 ;{ }^{* *} p<0.001$ 
Table 2. Concentration of antibodies to tetanus toxoid (ATTx) in sera of non irradiated rats during the experiment

\begin{tabular}{|c|c|c|c|}
\hline \multirow{2}{*}{ Day of experiment } & \multicolumn{3}{|c|}{ Experimental group } \\
\cline { 2 - 4 } & $\mathrm{K}_{1}$ & $\mathrm{~K}_{2}$ & $\mathrm{~K}_{3}$ \\
\hline \hline 0. day & $19.60 \pm 5.21$ & $18.60 \pm 3.75$ & $19.40 \pm 4.99$ \\
\hline 28. day & $336.60 \pm 6.53$ & $571.50 \pm 42.65$ & $20.10 \pm 2.92$ \\
\hline
\end{tabular}

K1 rats immunized with antitetanus vaccine on days 2 and 14 and treated with saline $(n=10)$ K2 rats immunized with antitetanus vaccine on days 2 and 14 and treated with thymus extract $(n=10)$ K3 non vaccinated rats treated with saline $(n=10)$

\section{IL-2 concentration}

After a single exposure to 4 or 6 Gy of ionizing radiation, all experimental animals had a reduction of IL-2 concentration in sera on the fourth day averaging $45 \%$ compared to levels before irradiation (Figure 1). Further follow up showed a gradual increase of IL-2 mean concentrations in the rat sera. In the A1 subgroup (rats irradiated with $4 \mathrm{~Gy}$ ), IL-2 concentrations rose by the seventh day, and this increase was evident until the end of the experiment, but for a reduction on day 11. The highest concentration was recorded on day 21.

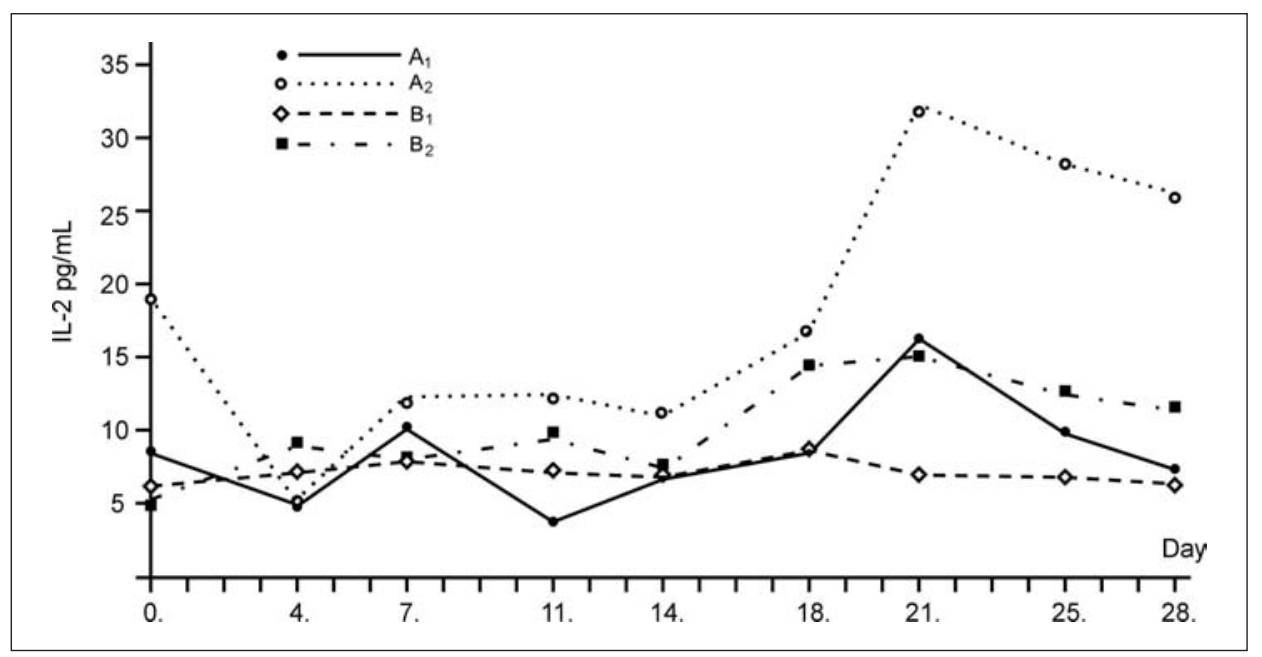

Figure 1. Changes in serum IL -2 concentrations during the experiment

$A_{1}$ rats irradiated with 4 Gy and treated with saline $(n=40)$

$A_{2}$ rats irradiated with 4 Gy and treated with thymus extract $(n=40)$

$B_{1}$ rats irradiated with 6 Gy and treated with saline $(n=40)$

$B_{2}$ rats irradiated with 6 Gy and treated with thymus extract $(n=40)$

In B1 subgroup, in which rats were irradiated with $6 \mathrm{~Gy}$, only smaller oscillations of mean IL-2 concentratios were registered during the experiment. 
The highest concentration was measured on day 18 but we didn't observe a tendency of elevation as in group A1.

Comparing the mean concentrations of IL-2 between groups A1 and B1 statistically significant differences were noted on day 11 at $a p 0.05$ level, and then on day 21 at a level of significance of $p \leq 0.01$ in favor of group A1.

In rats irradiated with single dose of 4 or 6 Gy that were treated with bovine thymus extracts, there was a gradual increase of IL-2 concentrations in sera from day 7 , until the end of the experiment. The highest concentration of IL-2 in sera of rats recieving 4 Gy dose and subsequentily recieving the extract, the highest concentration was achieved on day 21. This difference has a high statistical significance $(p \leq 0.001)$ compared to concentrations on day 4 of the experiment. After that, we noted a slight decrease of IL-2 concentration, but on day 21 they were still significantly higher than on day $4(p \leq 0.01)$.

Comparing IL-2 concentrations in the subgroup treated with bovine thymus extract with the levels in the subgroup that was not treated, from day 11 there are statistically significant differences in group A, and from day 21 in group B. The subgroups that were treated with thymic extract after irradiation had higher concentrations of IL-2 in sera. The concentrations in subgroup B2 were lower than in subgroup A2 and the difference was statistically significant on days 21 and 28 $(p \leq 0.05)$ and highly significant $(p \leq 0.01)$ on day 25 (Table 1$)$.

\section{IFN- $\gamma$ concentration}

On the fourth day after a single dose irradiation of the experimental animals with 4 or $6 \mathrm{~Gy}$, all individuals had a decrease of IFN- $\gamma$ concentrations in sera (Figure 2). In the subgroup A1 the fall was by $17 \%$, and in subgroups B1: $57 \%$, B2: $29 \%$, compared to initial values. The reduction of sera IFN- $\gamma$ in subgroup $A 1$ continued until day 11, and in subgroup B1 until day 14, with small oscillations. After that, there was an increase of serum IFN- $\gamma$ concentrations in both subgroups, but mean concentrations measured on day 28 were lower when compared to initial concentrations. In our research we did not register statistically significant differences in IFN- $\gamma$ concentrations between sera of different subgroups recieving different doses of irradiation.

Rats recieving a single radiation dose of 4 or 6 Gy that were treated with bovine thymus extract, had an increase of IFN- $\gamma$ levels in sera by day 7 in both subgroups and this trend continued until day 28 of the experiment. The mean concentrations registered for both subgroups at the end of the experiment were higher than pre-radiation values and during the first days after irradiation. The difference was statistically highly significant $(p \leq 0.01)$ in subgroup $A 1$ and significant $(p \leq 0.05)$ in subgroup B2.

Analyzing the mean concentrations of IFN- $\gamma$ in subgroups treated with bovine thymus extract and groups that did not recieve this treatment, on days 7 and 11 we registered statistically significant differences in group $A(p \leq 0.05)$ and highly significant difference $(p \leq 0.01)$ on day 28 (Table 1$)$. In group B we noticed highly significant differences $(p \leq 0.01)$ on day 14 between subgroups $B 1$ and B2, and on day 21 and 28 the difference was significant at the level of $p \leq 0.05$. 
Analyzing the mean concentrations of IFN- $\gamma$ in sera of rats recieving different doses of ionizing radiation we found no statistical significance between subgroups $\mathrm{A} 1$ and $\mathrm{B} 1$ and $\mathrm{A} 2$ and $\mathrm{B} 2$.

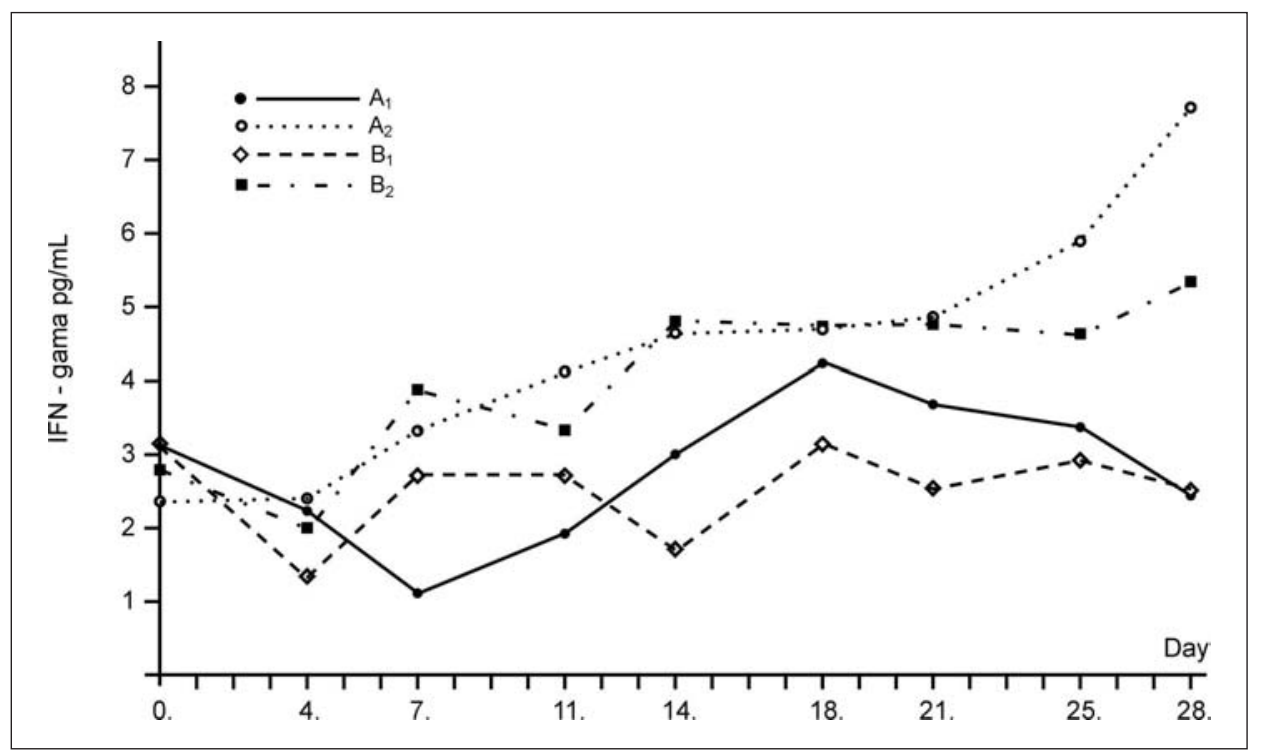

Figure 2. Changes in serum IFN- $\gamma$ concentrations during the experiment

$A_{1}$ rats irradiated with 4 Gy and treated with saline $(n=40)$

$A_{2}$ rats irradiated with 4 Gy and treated with thymus extract $(n=40)$

$B_{1}$ rats irradiated with 6 Gy and treated with saline $(n=40)$

$B_{2}$ rats irradiated with 6 Gy and treated with thymus extract $(n=40)$

\section{Skin hyper-reactivity to $P H A$}

On day 7, after rat irradiation with 4 or $6 \mathrm{~Gy}$, there was a decrease of skin hypersensitivity to PHA. In subgroups A1 and B1 we demonstrated a lower level of reactivity compared to control values at the begining of the experiment $(p \leq 0.01)$ (Figure 3). At the second mesurement, on day 14, in both subgroups there was an increase of skin reactivity and this increasing trend continued through days 21 and 28. During the experiment there was no statistically significant difference in skin reactivity to PHA between subgroups that were not treated with bovine thymus extract.

In the experimental group $A$, on day 7 , we noted statistically highly significant differences $(p \leq 0.01)$ between treated and not treated groups of rats (A1 and A2), as shown in Table 2. Following that, on day 14, the differences were not significantly different. Statistically significant differences in CBHR $(p \leq 0.05)$ between these groups were found again on days 21 and 28 . In the second experimental group (B) statistically significant differences $(p \leq 0.05)$ were found on day 14 between groups B1 and B2 and these differences were maintained until 
the end of the experiment. In rats that were not treated with bovine thymus extract there were no significant differences between mean values of this test. In rats that were treated with bovine thymus extract after irradiation with 4 or $6 \mathrm{~Gy}$, there were highly significant $(p \leq 0.01)$ differences on day 7 and statistically significant $(p \leq$ $0.05)$ differences on day 21.

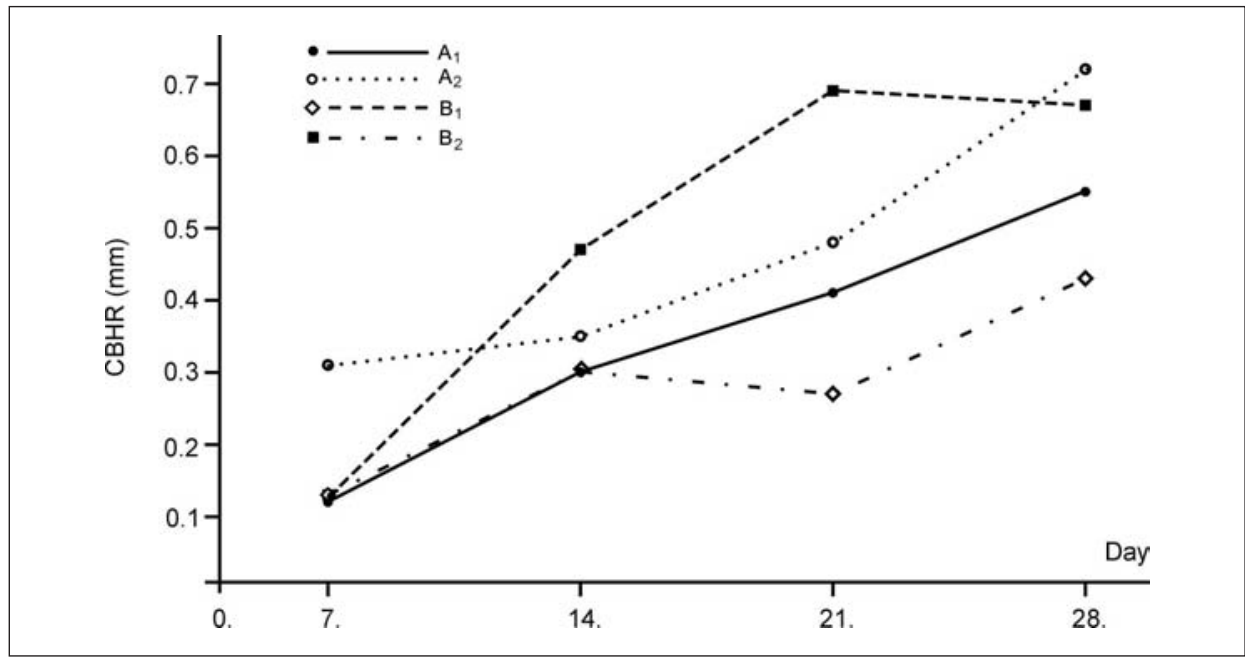

Figure 3. Changes in $\mathrm{CBHR}$ to PHA during the experiment

$A_{1}$ rats irradiated with 4 Gy and treated with saline $(n=40)$

$A_{2}$ rats irradiated with 4 Gy and treated with thymus extract $(n=40)$

$B_{1}$ rats irradiated with 6 Gy and treated with saline $(n=40)$

$B_{2}$ rats irradiated with 6 Gy and treated with thymus extract $(n=40)$

\section{ATTx humoral immune response}

After a single irradiation of experimental animals with 4 or 6 Gy, all rats from experimental groups A and B had increased sera concentrations of ATTx on the day 7 , as a result of primary antitetanus vaccination (Figure 4). The differences in sera ATTx values were statistically highly significant $(p \leq 0.001)$ when compared to pre-irradiation and pre-vaccination concentrations. In the experimental group $\mathrm{C}$, in which animals were not vaccinated, ATTx concentrations were generally on the low level and slightly decreased after irradiation, but without statistical significance (Figure 5).

The highest mean concentrations of ATTx were recorded in animals irradiated with 4 Gy and treated with thymus extract. Moreover we found a marked increase of antibody concentrations in both experimental groups especially on day 21 following revaccination on day 14 . At the end of the experiment, on day 28 , the ATTx concentrations in subgroups $A 1$ and B1 were significantly higher $(\mathrm{p} \leq$ 0.001 ) than at the beginning of the experiment or at day 7 after primary vaccination (Table 3). 


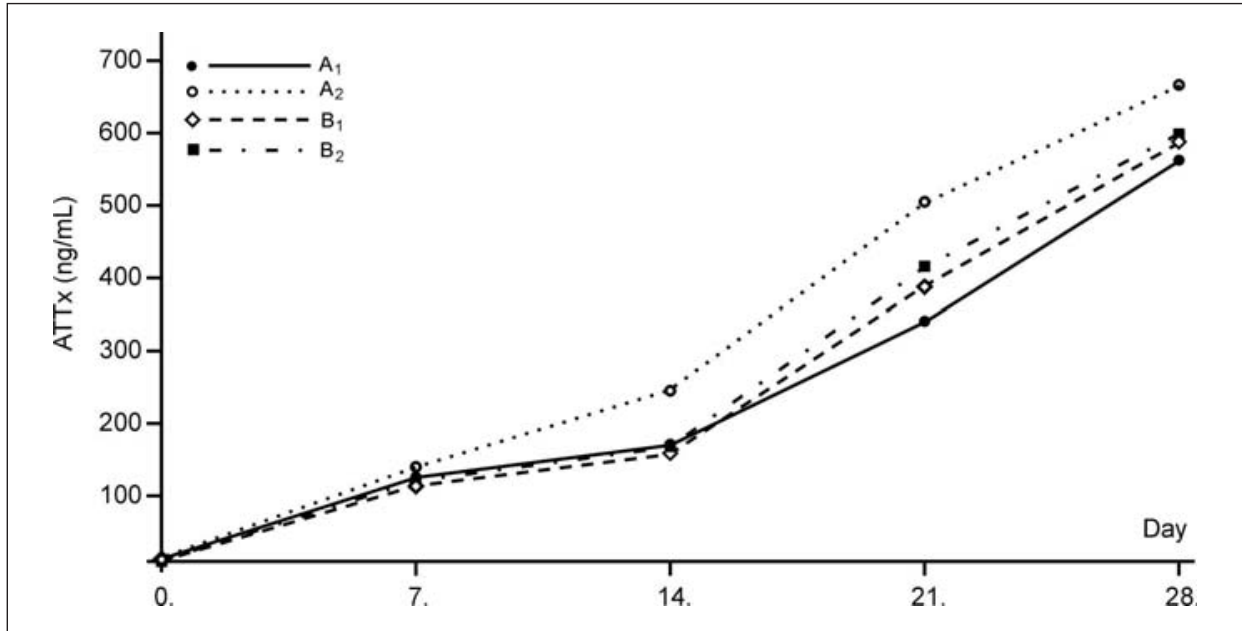

Figure 4. Changes in concentration of antibodies to tetanus toxoid (ATTx) in sera of irradiated rats during the experiment

$A_{1}$ rats irradiated with 4 Gy and treated with saline $(n=40)$

$A_{2}$ rats irradiated with 4 Gy and treated with thymus extract $(n=40)$

$B_{1}$ rats irradiated with 6 Gy and treated with saline $(n=40)$

$B_{2}$ rats irradiated with 6 Gy and treated with thymus extract $(n=40)$

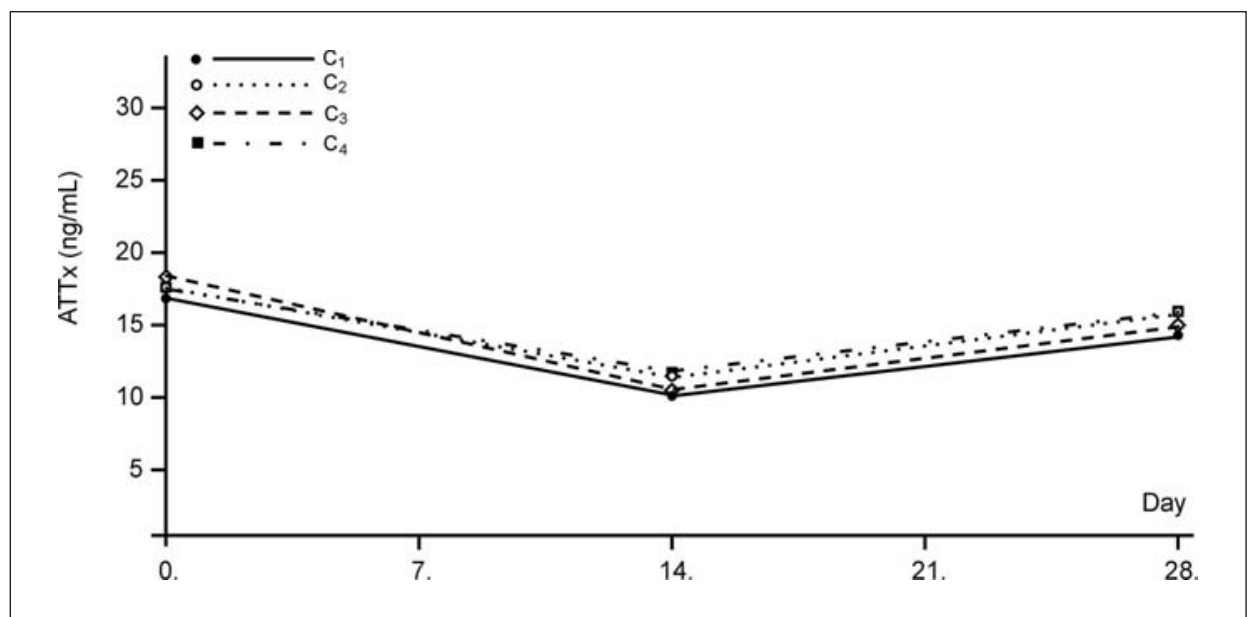

Figure 5. Changes in concentration of antibodies to tetanus toxoid (ATTx) in sera of irradiated but non vaccinated rats during the experiment

$A_{1}$ rats irradiated with 4 Gy and treated with saline $(n=40)$

$A_{2}$ rats irradiated with 4 Gy and treated with thymus extract $(n=40)$

$B_{1}$ rats irradiated with 6 Gy and treated with saline $(n=40)$

$B_{2}$ rats irradiated with 6 Gy and treated with thymus extract $(n=40)$ 
Table 3. Statistical differences betveen concentration of antibodies to tetanus toxoid (ATTx) and degree of cutaneus basophyl hipersensitivity (CBHR) in experimental grups of Wistar rats

\begin{tabular}{|c|c|c|c|c|c|}
\hline & & $A_{1}$ vs $A_{2}$ & $\mathrm{~B}_{1}$ vs $\mathrm{B}_{2}$ & $A_{1}$ vs $B_{1}$ & $A_{2}$ vs $B_{2}$ \\
\hline \multirow{2}{*}{ 7. day } & ATTx & NS & NS & NS & * \\
\hline & CBHR & ** & NS & NS & ** \\
\hline \multirow{2}{*}{ 14. day } & ATTx & $\star \star \star$ & NS & NS & ** \\
\hline & $\mathrm{CBHR}$ & NS & * & NS & NS \\
\hline \multirow{2}{*}{ 21. day } & ATTx & $\star \star \star *$ & NS & * & $\star \star$ \\
\hline & CBHR & * & * & NS & * \\
\hline \multirow{2}{*}{ 28. day } & ATTx & ** & NS & NS & $\star \star$ \\
\hline & CBHR & * & * & NS & NS \\
\hline
\end{tabular}

NS - non significant; ${ }^{*} p<0.05 ;{ }^{* *} p<0.01 ;{ }^{* * *} p<0.001$

Analyzing the concentrations of antibodies to tetanus toxoid in sera of animals from experimental subgroups $\mathrm{A} 1$ and $\mathrm{B} 1$ which received different radiation doses, we were able to demonstrate only small differences: antibody concentrations were higher in animals receiving smaller irradiation doses. These differences were not statistically significant (Table 3), except on day 21 ( $p \leq 0.05$ ).

Rats receiving 4 or 6 Gy and treated with thymic extract had a gradual increase of ATTx concentrations beginning on day 7 until the end of the experiment. Analyzing the mean sera concentrations of ATTx in treated rats, only in the experimental group A (A1 and A2) we noted statistically highly significant $(p \leq 0.001)$ differences in favor of the subgroup A1 from day 14 until the end of the experiment. Comparing the mean concentrations of sera ATTx in rats receiving different radiation doses (A2, B2), on day 7 there was a significantly higher concentration in subgroup A2 and this difference was maintained until the end of the experiment. At days 14 and 28 the differences were highly significant $(p \leq$ 0.01).

The positive effect of bovine thymus extract was also evident in the control group K2. In this group, on day 28, the difference in ATTx concentrations was statistically highly significant $(p \leq 0.001)$ in comparison to the control group $\mathrm{K} 1$. In the third group (K3) in which experimental animals were not vaccinated (or revaccinated) with antitetanus vaccine there were no concentration variations of ATTx during the experiment (Table 2).

\section{DISCUSSION}

The results of this study indicate that the negative effects of $X$ ray irradiation on the immune response can be reduced by bovine thymus extract acting as an immunostimulator. 
The changes in IL-2 concentrations because of radiation are caused by thymus damage and thymocyte apoptosis. The extent of the damage and apoptosis depend on the received quantity of radiation (Adachi et al., 2005; Mizutani et al., 2002). IL-2 synthesis takes place in T cells, and they are the first ones to disappear in the damaged thymus. It is clear that the concentration of this interleukin decreases in the first days after radiation. After normal cellularity of the thymus is regained gradually, after day 7 after irradiation, there is a gradual increase of IL-2 concentrations in the sera.

After a single irradiation of rats in a dose of 6 Gy, Mizuni et al. (2002) registered high numbers of apoptotic thymocytes in the thymus cortex. At the same time, they registered a decrease of serum IL-2 to a lesser extent than in our experiment. After that, from experimental day 5 , they found a diminishing number of apoptotic cells and a gradual increase of the number of thymocytes in the cortex. The same author demonstrated an increased macrophage activity because of the removal of apoptotic cells and also an increase of cytokines such as IL-2 and INF- $\gamma$. In further measurements, Mizutani et al. (2002) did not find significant changes in IL-2 concentrations in the sera of irradiated rats.

Adachi et al. (2005) investigated changes in the thymus of rats irradiated with 8 Gy and determined the concentration of IL-2 in their sera. On day 3 after irradiation, they registered a slight increase in the concentration of IL-2 followed by a rapid decrease after day 5 to day 14 . A statistically significant increase was registered on day 21 , after which, on day 28 , the levels of IL-2 return to preirradiation values. The authors connect this dynamics to changes in the thymus, as IL-2 is synthesized in activated young thymocytes. This irradiation dose lead to greater damage in the thymus so that recovery was prolonged and a statistically significant concentration increase was achieved only by day 21 . In our study, in rats receiving dose of 6 Gy of radiation, a significant increase of IL-2 concentrations was reached on day 18.

A positive effect and a better cellular response in rats treted with the bovine thymus extract were demonstrated by Jankovic and Maric (1988). They found that, in rats, in which the thymus was surgically removed, bovine thymus extract improves the cellular immune response. Goldstein et al., (1978) found that in mice with genetic thymus aplasia, bovine thymus extract was beneficial on lymphokine production as well as on T cell and NK cell functions.

Fattah et al. (1999) studied the effect of bovine thymus extract on chicken. They noticed an improvement of the cellular immune response caused by the increase in T lymphocyte numbers and IL-2 concentrations.

Numerous authors described the favorable effect of bovine thymus extracts on IL-2 production in vitro in immunodefficient patients. Ben-Efraim et al. (1999), Grumberg et al. (1997) and Schulye-Forster (1997) showed that bovine thymus extract increases the cytotoxic effect of NK cells activated through IL-2 on tumor cells. Bovine thymus extract increased the secretion of IL-2 and also the expression of IL-2 receptors on activated T cells.

It is well documented that different immunodefficiences in humans request different immunostimulants. Frega et al. (1994) and Skomicki et al. (1994) investigated the effect of bovine thymus extracts in HIV positive individuals. They 
found that, in vitro, these extracts significantly increase IL-2 production in both infected and non-infected patients. This is in accordance with our results because we were also able to demonstrate that in sera in non-irradiated (control) group of rats an increase of IL-2 was clearly evident. However, unlike from our findings, IL-2 in immunodefficient humans never reaches the values of the control groups. In our study rats irradiated with 4 Gy had IL-2 levels on day 28 similar to those in the control group that also received the thymic extract. Rats that received 6 Gy of radiation had IL-2 levels inferior to $50 \%$ of those in the control group and also compared to the group receiving $4 \mathrm{~Gy}$. Based on these data, we may conclude that the level of IL-2 depends on the degree of immunodeficiency.

The changes in IFN- $\gamma$ concentrations in sera originate from thymus damage and thymocyte apoptosis due to irradiation. It has already been stated that dose dependent radiation damages the thymus and leads to thymocyte apoptosis (Adachi et al., 2005; Mizutani et al., 2002). IFN- $\gamma$ is synthesized in T cells $\left(T_{H} 1\right)$ and NK cells and they are the first to disappear in the damaged thymus, thus the concentration of this interferon is reduced in the first days after irradiation. After day 7 , with thymus recovery accompanied by normal cellularity, there is a gradual increase in IFN- $\gamma$ concentration in the serum. The results obtained by Adachi et al., (2005) are in agreement with our results. In their experiment, after a single dose irradiation of rats, there was a moderate decrease of IFN- $\gamma$ concentrations in sera. This decrease was maintained until day 11 of the experiment followed by statistically significant increase in IFN- $\gamma$ sera concentrations. On days 21 and 28 we noted a decrease of mean IFN- $\gamma$ concentrations. The obtained values were lower than before irradiation and this result was interpreted as a radiation effect on the thymus and the time needed for complete recovery and renewal of normal cellularity in irradiated individuals.

Mizutani et al. (2002) registered a decrease of mean concentrations of IFN- $\gamma$ in sera of subletally irradiated rats. They also reported an increase of IFN- $\gamma$ concentrations that was statistically highly significant $(p \leq 0.01)$ following administration of proinflamatory cytokines on days 5 and 7 .

There are few records about the effects of thymus extract on the immune status of animals and humans. The effects of bovine thymus extract treatment on the cellular immune response in chicken, including IFN- $\gamma$, were studied by Fattah et al. (1990). The authors found an improvement of the cellular immune response because of an increase of T lymphocyte counts and IFN- $\gamma$ concentration in sera. In vitro experiments showed that different extracts or extract fractions of the bovine thymus had a positive effect on T cells and production of IFN- $\gamma$, as well as other factors of the immune cellular response. (Ben-Efraim et al., 1999; Grunberg et al., 1997; Schulze-Forster, 1997). In our recent study we were able to demonstrate that treatment of irradiated Wistar rats with thymic extract, resulted in a significant impovement of hematological parameter values that may be associated with cytokine production (Jovanović et al., 2006).

Cutaneous hypersensitivity testing was used by numerous authors as an indicator of cellular immune response. In rats that received, after immunosuppression, different preparations of bovine thymus extracts or their 
fractions, a higher level of cutaneous hypersensitivity was documented (Jankovic, 1992; Jankovic and Maric, 1988; Maric et al., 1991a).

Phytohemagglutinin was used in vitro conditions to control thymocyte proliferation in immunosuppressed individuals. Ominska-Domoratzka et al., (2002) in mice and Barboza et al. (2000) in dogs, followed the effects of bovine thymus extracts on the mitogenesis (proliferation) of T cells stimulated by PHA or Con A. In both studies authirs proved a positive effect of the bovine thymus extracts on the cellular immune response and T cell proliferation.

The level of antibodies after ionizing radiation depends on the radiation dose and the time interval between irradiation and antigen exposure. Mankindan and Price (1972) found an absence of the primary humoral immune response after antigen exposure in the first 24 hours. Stewart and Perez (1976) found suppression of the humoral immune response in mice recieving sublethal doses of radiation. The humoral immune response depends on the renewal of $\mathrm{T}$ and $\mathrm{B}$ cells. With lower radiation dosage, after a few days $(7-10)$, there is a gradual increase in antibody concentrations (Sharp and Watkins, 1981).

Ben-Efraim et al. (1999) registered the positive effect of bovine thymus extracts on the humoral immune response with increased antibody levels. Jankovic and Maric (1988) registered a statistically significant $(p \leq 0.001)$ increase in antibodies in 8 and 22 week-old thymectomized rats that were immunized with sheep erythrocytes and then treated with Thymex-L, compared to an untreated group of rats of the same age. Maric et al. (1991b) registered the positive effects of bovine thymus extracts in 8 and 17 week old rats that were immunized with sheep erythrocytes and treated with bovine thymus extracts.

The positive effect of bovine thymus extracts on the humoral immune response was also registered in chicken. Fattah et al. (1999) found a statistically significantly higher concentration of antibodies in chicken vaccinated against IBVD (Infectious Bursal Disease Virus) treated with bovine thymus extracts when compared to untreated controls.

Bovine thymus extracts have positive effects on human humoral immune responses. In elderly patients that were given bovine thymus extracts after antitetanus vaccination, the registered increase of antitetanus antibody concentrations was statistically significant when compared to untreated individuals and pre-experimental levels (Jankovic et al., 1988; Fagiolo et al., 1993).

\section{CONCLUSIONS}

Based on the obtained data, it can be concluded that a single 4 or 6 Gy irradiation of rats with $X$ rays, produces a decreased cellular and humoral immune response and a significant decrease in serum concentrations of IL-2, IFN- $\gamma$ and ATTx and decreased cutaneous hypersensibility to PHA. After administration of bovine thymus extracts every other day to irradiated rats, there was an increase of IL-2, IFN- $\gamma$ and ATTx serum concentrations and an increase in cutaneous hypersensibility to PHA. A statistically significant increase of these parameters 
was registered from day 7 for IL-2, IFN- $\gamma$ and ATTx, and from day 14 for cutaneous hypersensibility, and it was maintained until the end of the experiment.

ACKNOWLEDGEMENT:

This investigations were supported by the Serbian Ministry of Science and Environmental Protection, Grant No 143022.

Address for correspondence:

Dr Milan Jovanović

Faculty of Veterinary Medicine

Bul. oslobođenja 18

11000 Beograd Serbia and Montenegro

e-mail: milanjov@vet.bg.ac.rs

\section{REFERENCES}

1. Adachi Y, Tokuda N, Sawada T, Fukumoto T, 2005, Semiquantitative Detection of Cytokine Message in X-Irradiated and Regenerating Rat Thymus, Rad Res, 163, 400-7.

2. Barboza G, Rivera S, Parra O, Fernandez G, Ramirez R, Otero C, 2000, Evaluation of immunological response in canines infecdet with demodectic mange after tretment with Amitraz or Thymostimulin Tp-1, Revista cientifica-Fac de Ciencias Veterinarias, 10, 2, 145-52.

3. Benedikt $H, 2000$, The use of Thymus supplementation, A Novel Approch to Immune Regulation, Orig Internist, 12, 25-32.

4. Ben-Efraim S, Keisari Y, Ophir R, Pecht M, Trainin N, Brustein Y, 1999, Immunopotentiating and immunotherapeutic effects of thymic hormones and factors ith special emphasis on thymic humoral factor TNF- 2 2, Crit Rev Immunol, 19, 4, 261-84.

5. Bethesda MD, 2001, Molecular and Cellular Biology of Moderate Dose (1-10 Sv) Radiation and Potential Mechanisms of Radiation Protection, Proceedings Moderate Dose Radiation Workshop Draft Report, 1-22.

6. Coggle JE, 1981, The absence of late effects of irradiation on the cellularity of the mouse thymus, Int J Radiat Biol, 40, 2, 229-32.

7. Fagiolo U, Amadori A, Biselli R, Paganelli R, Nisini R, Cozzi E et al, 1993, Quantitative and qualitative analysis of anti-tetanus toxoid antibody response in the elderly, Humoral immune response enhancement by Thymostimulin, Vaccine, 11, 13, 1336-40.

8. Fattah MA, El-Hamamy MM, El-Shahedy M, Gehad M, 1999, Effect of Thymus extract on Immunologic reactivity of Chiken Vaccinated with Infectious Bursal Disease Virus, J Vet Med Sci, 61, 7, 811-7.

9. Frega A, Di Renzi F, Stentella P, Pachi A, 1994, Management of human papiloma virus vulvo-perineal infection with systemic beta-interferon and thymostimulin in HIV-positive patients, Int J Gynecol Obstet, 44, 3, 255-8.

10. Goldstein LA, Thurman BG, Low KL, Teresa Rossio LJ, Trivers EG, 1978, Hormonal Influences on the reticuloendothelial System: Current status of the Role of Thymosin in the Regulation and Modulation of Immunity, J Reticuloendothe/ Soc, 23, 4, 253-66.

11. Goto N, Kodama H, Okada, K, Fujimoto Y, 1978, Suppression of phytheamagglutinin skin response in thymectomized chickens, Poult Sci, 57, 246-50.

12. Greave MF, Roitt IM, 1968, Effect of bursectomy and thymectomy on the responses of chicken periferal blood lymphocytes to phytoheamagglutinin, Nature, 220, 293-5.

13. Grunberg Elke, Eckert K, Rainer Maurer H, 1997, Prothymosin $\alpha 1$ enhacens the interleukin-2 activated killer cell adhesion to and immunotoxicity against docetaxel-treated $\mathrm{HT}-29$ colon carcinoma cells in vitro, Int $J$ Thymol, 5, 8+9, 415-23. 
14. Janković $D B$, Marić $D, 1988$, Restoration of in vivo humoral and cell-mediated immune responses in neonatally thymectomized and aged rats by means of lipid and protein fractions from calf thymus, Ann NY Acad Sci, 521, 228-46.

15. Janković DB, Korolija P, Isaković K, Popesković Lj, Pešić ČM, Horvat J et al, 1988, Immunorestorative effects in elderly humans of lipid and protein fractions from the calf thymus: A double-blind study, Ann NY Acad Sci, 521, 247-59.

16. Janković $D B, 1992$, In vivo immunostimulatory activity of bovine Prothymosin- $\alpha 1$, Thymuspeptide Timusenzime Thymushormone in Forschung und Therapie. Thymus Medizinischer fachbucherlag, bad Harzburg, 25-34.

17. Jovanović $M$, Lazarević $M$, Popović $N$, Eurđević $D, 2006$, The influence of thymic extract on hematological parameter values in irradiated Wistar rats, Acta Veterinaria, Belgrade, 56, 2-3, 137-48.

18. Lake FD, Akporiaye TE, Hersh ME, 2001, Immunopharmacology, In Basic \& Clinical Pharmacology, By Katzung GB, 8th edition, Lange Medical Books/Mcgraw-Hill, 959-86.

19. Marić D, Reljić J, Ranin J, Janković DB, 1991a, In vivo effect of Prothymosin- $\alpha 1$ on humral and cellmediated immune responses in the young rat, Intern $J$ Neurosci, 59, 135-42.

20. Marić D, Janković DB, Veljić Jelena, 1991b, Immunostimulatory activity of Prothymosin-Alfa in senescence, Ann NY Acad Sci, 621, 148-58.

21. Mankinodan T, Price GB, 1972, Circumventing graft rejection. In Transplantation, Najarian JS, Simmons RL, eds., Lea \& Febiger, Pennsylvania, 251-71.

22. Mizutani N, Fujikura Y, Wang Y, Tamechika M, Tokuda N, Sawada T et al, 2002, Inflamatory and Antiinflammatory Cutokines Regulate the Recovery from Sublethal X Irradiation in Rat Thymus, Radiat Res, 157, 3, 281-9.

23. Munno I, Marinaro M, Gesario A, Cannuscio, B, Mishel Y, Paulling E, 1995, Immunomodulatory Effects of Alfa Interferon and Thymostimulin in patient with neoplasias, Clin Diag Lab Immunol, 2, 4, 503-5.

24. Nesterova IV, 1999, Modern Immunotherapy in Clinical Medicine, Present and Future, Russ $J$ Immunol, 4, 4, 322-6.

25. Obminska-Domoradzka B, Szczypka M, Debowy J, 2002, Effects of thymomimetic drugs and zinc supplementation on response in hydrocortisone-suppressed mice, $J$ Vet Med B, Infect Dis Vet Public Health, 49, 10, 469-75.

26. Schulze-Forster K, Heidecke H, Rainer Maurer H, 1997, Prothymosin $\alpha 1$ enhances the in vitro-LAK cell activity of the human NK-like cell line YT measured by a rapid colorymetric assay, Int $J$ Thymol, 5, 8+9, 424-30.

27. Sharp JG, Watkins EB, 1981, Cellular and immunological consequences of thymic irradiation, In Immunopharmacologic effectss of radiation therapy, Raven Press, 137-79.

28. Simonsen O, Bentzon MW, Heron I, 1986, ELISA for the routine determination of antitoxic immunity ti tetanus, J Biol, 14, 3, 231-39.

29. Skotnicki BA, Zatz MM, Sztein BM, Goldstein LA, Schulofm SR, 1994, The in vitro effect of thymic hormones on IL-2 production by lymphocytes from HIV-seropositive pre AIDS (ARC) subjects implications for therapeutic trials, Int J Thymol, 2, 4, 188-95.

30. Smits JE, Bortolotti GR, Tella JL, 1999, Simplifyng the phytoheamagglutinin skin-testing technique in studies of avian immunocompentence, Funct Ecol, 13, 567-72.

31. Stewart CC, Perez CA, 1976, Effects of irradiation on immune response, Radiology, 118, 201-10.

32. Tizard RI, Schubot MR, 2004, Veterinary Immunology, An Introduction, 7th edition, W.B. Sounders Company, Philadelphia.

33. Tokuda N, Hamasaki K, Mizutani N, Adaci Y, Sawada T, Funahashi H et al, 2004, Expression of PAC1 receptor in rat thymus after irradiation, Regul Pept, 123, 167-72.

34. Twomey JJ, Koutab NM, 1982, Selected phenotypic induction of null lymphocytes from mice with thymic and nonthymic agents, Cell Immun, 72, 186.

35. Vos JG, Buys J, Beekhof P, Hagenaars AM, 1979, Qualification of total IgM and IgG and specific IgM and IgG to thymus-independent (LPS) and thymus-dependent (tetanus toxoid) antigen in rat by enzyme-linked immunosorbent assey (ELISA), Ann NY Acad Sci, 320, 518-34. 


\title{
EFEKAT EKSTRAKTA GOVEĐEG TIMUSA NA IMUNSKI ODGOVOR OZRAČENIH WISTAR PACOVA
}

\author{
JOVANOVIĆ M, LAZAREVIĆ M, POPOVIĆ N i VOJVODIĆ D
}

\begin{abstract}
SADRŽAJ
Pojedini sastojci ekstrakta goveđeg timusa imaju imunomodulatorna svojstva i mogu, kod ljudi i životinja, sa suprimiranim funkcijama imunskog sistema (humoralnim i/ili celularnim) dovesti do imunostimulacije. U ovom radu su prikazani rezultati ispitivanja efekata preparata Thymex-L dobijenog iz ekstrakta goveđeg timusa na parametre humoralnog imunskog odgovora pacova kod kojih je prethodno izvršeno jednokratno ozračivanje X zracima u dozi od 4 ili 6 Gy. Određivani su sledeći parametri: koncentracija interleukina 2 (IL-2), interferona $\gamma$ (IFN- $\gamma$ ), koncentracija antitela posle vakcinacije i revakcinacije tetanusnim toksoidom (ATTx) i stepen kožne preosetljivosti (CBHR) na biljni mitogen (PHA) Ispitivani ekstrakt je ispoljio pozitivan efekat na koncentraciju IL-2 i IFN- $\gamma$ u serumu ozračenih pacova. Ovaj pozitivan efekat je, kod grupe pacova koja je primila nižu dozu zračenja, vidljiv već nakon 7. dana eksperimenta, dok je kod pacova ozračenih višom dozom zračenja pozitivan efekat registrovan 21. dana eksperimenta. Pri proceni stepena reakcije kožne preosetljivosti na PHA, registrovan je pozitivan efekat primenjenog ekstrakta timusa i on je bio izraženiji kod jedinki kod kojih je bila primenjena niža doza zračenja. Ispitivani ekstrakt goveđeg timusa je ispoljio pozitivan efekat i na koncentraciju ATTx i to već 14. dana eksperimenta.
\end{abstract}

